\title{
The Rohingya Crisis And International Displaced Aggression In Indonesia
}

\author{
Shary Charlotte Henriette Pattipeilhy, S.IP, M.A ${ }^{1}$, Dr. Reni Windiani, M.S ${ }^{2}$ \\ ${ }^{1}$ Fakultas Ilmu Sosial dan Ilmu Politik, Universitas Diponegoro, sharycharlotte@lecturer.undip.ac.id \\ ${ }^{2}$ Fakultas Ilmu Sosial dan Ilmu Politik, Universitas Diponegoro, reniwindiani@gmail.com
}

\begin{abstract}
This article seeks to analyze the social situation in Indonesia, where the conflict that occurred overseas manifested into violent actions against person or group within the country, who is considered to have a similar identity with overseas perpetrators. This pattern of violence is perpetrated against minority groups in Indonesia who have no involvement in conflict abroad. Some impacts of the Rohingya crisis in Indonesia are ranging from forced closure threat to Vihara in Medan, a demonstration on Buddhist religious symbols, beating against a Buddhist monk, and even bomb terror in Vihara. In social psychology theory, this violence is part of Defense Mechanism theory called Displacement. Furthermore, to answer why this displaced aggression can occur in Indonesia, I use Social Identity theory that the reductionist view of singular affiliation creates a gap in understanding of 'Self' and 'Other.' It then creates an intergroup bias when individuals tend to prioritize their group (in-group) compared to other groups (out-group). At last, this situation also reaffirms the concept of imagined community by Benedict Anderson.
\end{abstract}

Keywords: displaced aggression, social identity, imagined community, Rohingya, Indonesia

\begin{abstract}
ABSTRAK
Artikel ini berusaha untuk menganalisis peristiwa yang seringkali terjadi di Indonesia, dimana konflik yang terjadi di luar negeri kemudian dimanifestasikan dalam bentuk tindakan kekerasan terhadap orang-orang di dalam negeri yang dianggap memiliki kesamaan identitas dengan kelompok pelaku konflik di luar negeri. Pola kekerasan ini seringkali dilakukan terhadap kelompok minoritas dengan identitas yang berbeda di Indonesia yang sama sekali tidak memiliki keterlibatan dalam konflik di luar negeri. Artikel ini kemudian menganalisis konflik Rohingya di Myanmar yang memiliki imbas terhadap tindakan kekerasan terhadap Buddhist di Indonesia mulai dari teror bom, ancaman penutupan Vihara, hingga demonstrasi di simbol-simbol keagamaan Buddha di Indonesia. Kekerasan seperti ini dapat dianalisis menggunakan teori Defense Mechanism yakni konsep Displaced Aggression. Selanjutnya, Untuk menjawab mengapa displaced aggression ini dapat terjadi di Indonesia, maka saya menggunakan teori Identitas Sosial, dimana Identitas Sosial "Kami" melawan "Mereka" telah menciptakan bias antar kelompok sehingga masing-masing kelompok tersebut lebih mengutamakan kelompoknya sendiri dibandingkan kelompok lain. Selain itu, penggunaan konsep Imagined Community oleh Benedict Anderson juga menjadi sarana untuk menganalisis penyebab displaced aggression yang terjadi terhadap umat Buddha di Indonesia.
\end{abstract}

Kata Kunci: displaced aggression, identitas sosial, imagined community, Rohingya, Indonesia 


\section{Introduction}

Indonesia is a country with a unique identity. Despite being the largest Muslim-majority country in the world, Indonesia never declares itself as an Islamic state. The country continues to unite its nations within the broader ideological framework: Pancasila. The term Bhinneka Tunggal Ika or "Unity in Diversity" is being used since 1945 to bond different religious identity. Religious freedom is also protected under the laws and regulations made by the central and regional governments.

There are six legal religions in Indonesia: Islam; Christianity; Catholicism; Hinduism; Buddhism; and Confucianism. Based on the Indonesian Central Bureau of Statistics ${ }^{1}$ (see table 1), about 207,176,162 Indonesians are Muslim, and only 1,703,254 are Buddhists. Even if Christians, Catholics, Hindus, Buddhists, Confucians, and other religions were combined, the numbers remained far below Muslims. The large population of Muslims in Indonesia has made Islam as the most influential nationalism. However, for many political scientists who observed this country, Indonesia has become a positive example of haphazard about the incompatibility of Islam with secular democracy. ${ }^{2}$

\footnotetext{
${ }^{1}$ Badan Pusat Statistik Indonesia, "Statistik Politik 2017" (Jakarta, 2017).

2 Alfred C. Stepan, "Religion, Democracy, and the 'Twin Tolerations,", Journal of Democracy 11, no. 4 (2000): 37-57,

https://doi.org/10.1353/jod.2000.0088.
} 
Table 1 Comparison of Religious Adherents in Indonesia

\begin{tabular}{|l|l|c|}
\hline No & \multicolumn{1}{|c|}{ Religion } & Adherents \\
\hline 1 & Islam & $207,176,162$ \\
\hline 2 & Christianity & $16,528,513$ \\
\hline 3 & Catholicism & $6,907,873$ \\
\hline 4 & Hinduism & $4,012,116$ \\
\hline 5 & Buddhism & $1,703,254$ \\
\hline 6 & Confusianism & 117,091 \\
\hline 7 & Others & $1,196,317$ \\
\hline & Total & $237,641,326$ \\
\hline
\end{tabular}

Source: Badan Pusat Statistik Indonesia, "Statistik Politik 2017"

However, this country has also faced many intolerance issues and religious violence. The high number of Muslims in Indonesia has raised two religious differences: the majority of Muslims and the minority Non-Muslims. This binary opposition associated with violence against lower hierarchical minorities ${ }^{3}$.

The globalization of technology and the development of social media make international issues easier to access by societies and empower them with knowledge. However, without a proper filter of information, society can easily be provoked by hoaxes and hate speech.

After the fall of the New Order regime in 1997, government control over news and information in Indonesia has been minimalized. Communal issues or religiouspolitical issues on international level spreads widely and often creates violent conflict in Indonesia. The communal issue involving hostilities between religious communities, such as conflict of Muslims against nonMuslims.

The Rakhine conflict has become a burning topic in Indonesia from 2012 until 2017. This conflict took place in Myanmar, also known as Burma before this country changed its name to Myanmar in $1947^{4}$. The

\footnotetext{
${ }^{3}$ Jacques Derrida, Positions (Chicago: University of Chicago Press, 1981).

${ }^{4}$ Akm Ahsan Ullah, "Rohingya Refugees to

Bangladesh: Historical Exclusions and
}

stateless Muslim Rohingyas in the western state of Rakhine, have no access to jobs, healthcare, education, or any other public facilities in Myanmar. Even though the cause of this crisis is complex and varies (due to the war of perception) among domestic and international stakeholders ${ }^{5}$, In many Indonesian perspectives, the Rakhine crisis is seen as genocide or ethnic cleansing against Muslim Rohingya ${ }^{6}$. It is clear here that many studies identify this conflict is between Rohingya Muslims and Myanmar Buddhist ${ }^{7}$.

Contemporary Marginalization," Journal of Immigrant \& Refugee Studies 9, no. 2 (April 2011): 139-61, https://doi.org/10.1080/15562948.2011.567149. ${ }^{5}$ Gabrielle Aron, "Reframing the Crisis in Myanmar's Rakhine State," 2018, usip.org/publications/2018/01/reframing-crisismyanmars-rakhine-state; Azlan Tajuddin, "Statelessness and Persecution of the Rohingyas in Myanmar: Time for Serious International Intervention," Social Science Spectrum 3, no. 3 (2017): 128-40, http://www.socialspectrum.in/index.php/sp/article/ view/107/98.

${ }^{6}$ Aulia Rosa Nasution, "The Crime of Genocide on the Rohingya Ethnic in Myanmar from the Perspective of International Law and Human Rights," PADJADJARAN Jurnal Ilmu Hukum (Journal of Law) 5, no. 1 (May 13, 2018): 182206, https://doi.org/10.22304/pjih.v5n1.a10. ${ }^{7}$ Anna Yulia Hartati, "Studi Eksistensi Etnis Rohingya Di Tengah Tekanan Pemerintah Myanmar," JURNAL HUBUNGAN INTERNASIONAL 2, no. 1 (2013): 7-17, file://C:/Users/Shary/Downloads/297-906-1PB.pdf; Nasution, "The Crime of Genocide on the 
Diagram 1

Displaced Aggression in Indonesia

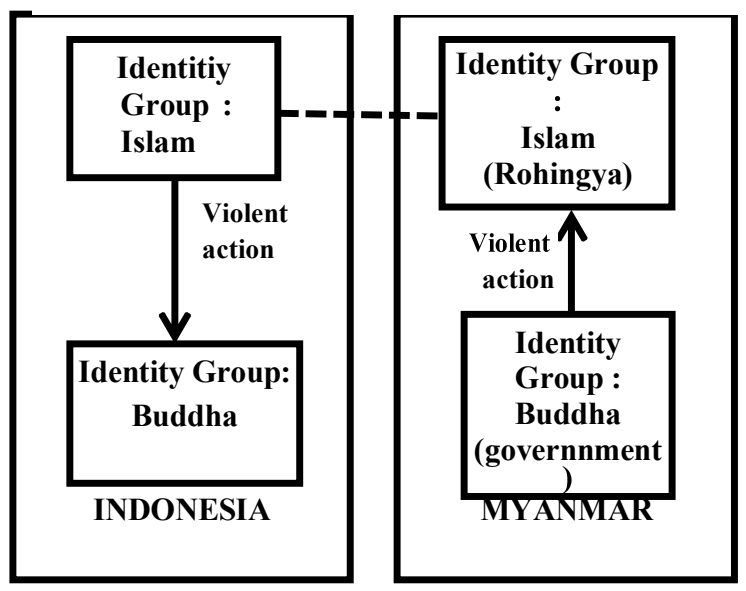

The result of this frivolous understanding is displaced aggression against Buddhist in Indonesia (see diagram 1).

The term aggression is chosen because this term has a holistic meaning, ranging from minor to severe violence. Minor violence such as name calling or any other verbal insult, and severe violence such as hitting, shooting, bomb terror, are part of aggression ${ }^{8}$. Violence is then considered as a subset of aggression:

"Thus, all acts of violence are considered instances of aggression, but not all acts of aggression are considered instances of violence. For example, a child pushing another child away from a favored toy would be considered aggressive but not violent. An extreme act, such as attempted murder, however, would be considered both aggressive and violent (with violent being the more descriptive term)." 9

The term displaced aggression is then understood as a robust social and psychological phenomenon resulted from

Rohingya Ethnic in Myanmar from the Perspective of International Law and Human Rights."

${ }^{8}$ Johnie J. Allen and Craig A. Anderson,

"Aggression and Violence: Definitions and

Distinctions," The Wiley Handbook of Violence and Aggression, September 8, 2017, 1-14, https://doi.org/10.1002/9781119057574.whbva001.

${ }^{9}$ Allen and Anderson. frustrations faced by one person or group, and it is being justified to conduct violent actions and aggression to the target who is not the cause of initial frustration ${ }^{10}$. This aggression target or scapegoats is chosen because they are available and safe targets ${ }^{11}$. The Buddhist is seen as a safe target since the number of its adherents is far below the Muslims, and their Indonesian nationality is seen as an available target.

The Muslim Rohingya gets tremendous sympathy from many Indonesians, who are also predominantly Muslim. Pressures to President Joko Widodo's administration to settle the crisis were thrown through

\footnotetext{
${ }^{10}$ Craig A. Anderson and Brad J. Bushman, "Human Aggression," Annual Review of Psychology 53, no. 1 (February 2002): 27-51, https://doi.org/10.1146/annurev.psych.53.100901.1 35231; William C. Pedersen, Candace Gonzales, and Norman Miller, "The Moderating Effect of Trivial Triggering Provocation on Displaced Aggression.," Journal of Personality and Social Psychology 78, no. 5 (2000): 913-27, https://doi.org/10.1037/0022-3514.78.5.913; Ronald J. Glossop, "Confronting War: An Examination of Humanity's Most Pressing Problem," Peace \& Change 10, no. 3-4 (October 1984): 181-82, https://doi.org/10.1111/j.14680130.1984.tb00534.x.

${ }^{11}$ Leonard Berkowitz, "Frustration-Aggression Hypothesis: Examination and Reformulation.," Psychological Bulletin 106, no. 1 (1989): 59-73, https://doi.org/10.1037/0033-2909.106.1.59.
} 
demonstrations ${ }^{12}$. However, Myanmar and Indonesia are members of the Association of Southeast Asian Nations /ASEAN who must adhere to the Non-Intervention Principle, and Indonesia could only provide humanitarian assistance to ease the suffering of Rohingya refugees. In several internal conflicts among ASEAN members, the non-intervention principle has created difficulties in resolving violent conflicts and humanitarian crisis in West Papua, Southern Thailand, and the Vietnam Degar minority ${ }^{13}$

Unfortunately, this humanitarian assistance deemed to be considered inadequate by some parties (especially political opponents of president Joko Widodo), who considers that the government should take tougher actions, especially to the government of Myanmar. Dissatisfaction over Joko Widodo's government to settle the conflict in Myanmar is then manifested by violence and threats against Buddhists in Indonesia.

Since 2012, there have been at least five cases of violence against Buddhists in Indonesia. The first case occurred in 2013, where there was a demonstration at Vihara Borobudur in Medan, North Sumatra, and the threat of forced closure of Vihara. This threat is meant to urge Buddhists in Indonesia to stop humanity crimes against Muslim Rohingyas in Myanmar ${ }^{14}$.

The second case was a bomb explosion inside the Ekayana Buddhist Vihara in West Jakarta in August 2013. The Ekayana Vihara

\footnotetext{
12 "Spreading Hatred against Buddhists 'Worsens Rohingya Conflict,"' The Jakarta Post, November 26, 2016,

https://www.thejakartapost.com/news/2016/11/26/s preading-hatred-against-buddhists-worsensrohingya-conflict.html.

${ }^{13}$ D H Tobing, "The Limits and Possibilities of the ASEAN Way: The Case of Rohingya as Humanitarian Issue in Southeast Asia," KnE Social Sciences 3, no. 5 (May 23, 2018): 148, https://doi.org/10.18502/kss.v3i5.2331.

${ }^{14}$ Bhagavant, "Demo Myanmar Yang Salah Alamat Di Vihara Borobudur Medan," 2013, https://berita.bhagavant.com/2013/05/06/demomyanmar-yang-salah-alamat-di-vihara-borobudurmedan.html.
}

caretaker saw a note on Closed Circuit Television (CCTV) recordings stating "We are responding to the cries of the Rohingyas" 15 .

The third case was the beating of a Buddhist monk named Chandasilo in Malang (Eastern Java province, Indonesia), by an Islamic State of Iraq and Syria / ISIS member named Salim Mubarak in February 2015. Salim Mubarak beat Chandasilo at the parking lot of Immigration Office in Malang. They were then taken to Malang Police Headquarters, and he (Salim) confessed that his action is based on anger against the persecution of Muslim Rohingya by Buddhist Myanmar ${ }^{16}$.

The fourth case occurred in June 2015, days before Vesak celebration, threats and hate speech against Buddhists in Indonesia spread widely in social media (Facebook and Twitter). The threats were directed against monks in Indonesia who is being accused of opposing supporters of Muslim Rohingya in Indonesia. The Buddhist monks are also mentioned as idolaters to celebrate Vesak in Borobudur, the largest temple in Indonesia. The provocation to prohibit Vesak day at the Borobudur temple was also spread widely ${ }^{17}$.

The last case occurred in September 2017. A mass organization called Islamic Defenders Front (Front Pembela Islam/FPI) raised its frustration on the Rakhine crisis by planning to stage a demonstration action at the Borobudur Temple area in Magelang, Central Java. However, the plan was thwarted due to cultural heritage law in Indonesia. Borobudur Temple is a sacred place for Buddhists and has

\footnotetext{
${ }^{15}$ Natahadibrata Nadya, "Bomb Threatens Pluralism," The Jakarta Post, 2013, https://www.thejakartapost.com/news/2013/08/06/b omb-threatens-pluralism.html.

16 Tempo, "Biksu Ini Beri Maaf Anggota ISIS Yang Pukul Dirinya," April 2, 2015, https://nasional.tempo.co/read/654874/biksu-iniberi-maaf-anggota-isis-yang-pukul-dirinya.

${ }^{17}$ Bhagavant, "Isu Rohingya, Buddhis Indonesia Kembali Dapat Ancaman Teror,” 2015, https://berita.bhagavant.com/2015/05/31/isurohingya-buddhis-indonesia-kembali-dapatancaman-teror.html.
} 
been established as one of world cultural heritage by the United Nations Educational, Scientific and Cultural Organisation / UNESCO. Therefore, its existence is highly protected by the Government. FPI and some Islamic mass organizations in Central Java have then held an action at mosque An Nuur, close to the Borobudur temple ${ }^{18}$.

These violence actions against Buddhists in Indonesia are considered inappropriate because sixteen Buddhist organizations who formally represent Buddhist communities in Indonesia has declared ten viewpoints of its position humanitarian crisis in Myanmar. On September 2017 they announced their ten viewpoints: (1) to understand that the conflict in Myanmar is not a religious conflict, but a humanitarian one; (2) to build solidarity to the Muslim Rohingya as a fellow human being;

(3) to stop acts of violence because it would only aggravate the situation; (4) to urge the Burmese government to uphold the human rights of the Rohingyas; (5) to reject any provocation on Myanmar's conflict in Indonesia (because it) could disrupt country's religious harmony; (6) to expect further cooperation between societies and police officers to stop the spread of hoaxes on Myanmar's conflict; (7) to expect the Indonesian government to ensure religious freedom in Indonesia; (8) to understand that there is no religion that supports terrorism; (9) to invoke any Indonesian Buddhist to not be provoked with issues that could disrupt religious harmony; (10) to urge Indonesian Buddhist to pray for an end of any violence against Muslim Rohingya ${ }^{19}$.

\footnotetext{
${ }^{18}$ Suherdjoko, "Peaceful Rohingya Solidarity Rally Held near Borobudur Temple," The Jakarta Post, September 9, 2017, http://www.thejakartapost.com/news/2017/09/09/pe aceful-rohingya-solidarity-rally-held-nearborobudur-temple.html.

${ }^{19}$ Yusron Fahmi, "Sikap Majelis-Majelis Agama Buddha Soal Kekerasan Atas Rohingya,"

September 3, 2017, https://www.liputan6.com/news/read/3080555/sika p-majelis-majelis-agama-buddha-soal-kekerasanatas-rohingya.
}

Here we can clearly see that the conflict occurred in Myanmar led to conflict and acts of violence against Buddhists in Indonesia, who had no connection with the conflict in foreign country. In fact, sixteen Buddhist community organizations have condemned the violence perpetrated by the Myanmar government against the Rohingyas. Therefore, this article seeks to answer why this displaced aggression occures in Indonesia?. This article aims to answer the causes of displaced aggression in Indonesia by using three main theories: displaced aggression; social identity; and imagined community.

\section{Theory}

The term displaced aggression is part of psychology studies, while cases that occur in Indonesia are part of sociology studies. The difference between these two sciences is that psychology studies the influence of social things on individuals, whereas sociology focuses on the collective phenomenon itself. Therefore, this article uses the terminology of international displaced aggression from psychological studies, but uses social science studies to answer why these cases can occur collectively in several regions in Indonesia. Hypotheses regarding the causes of international displaced aggression are (1) the strengthening of social identity which creates ingroup-outgroup segregation of "We" versus "Other"; (2) this segregation is also accompanied by an intergroup bias which views one group as a victim and other group as perpetrator, and finally (3) the nationalism of the Indonesian has faded due to the absence of a common enemy from other countries, and resulted in hostility towards fellow Indonesians. Therefore, three theories are used in this article: Social identity; intergroup bias; and imagined community.

The term displaced aggression is part of Sigmund Freud's theory on psychological defense mechanism theory that was developed by Gonzales and Miller from John Dollard's theory of Frustration-aggression (Pedersen, Gonzales, and Miller 2000b; Berkowitz 1989). 
In displaced aggression, the target of aggression is "innocent of any wrongdoing and just happens to be in the wrong place at the wrong time." (Pedersen, Gonzales, and Miller 2000a). Freud explained that displacement comes from the human subconscious who may have had unpleasant past experiences with certain objects or subjects (including its characteristic) (Freud 2004). When this substitute target has minor offense, the term triggered displaced aggression is used to understand the situation (Pedersen, Gonzales, and Miller 2000a). International displaced aggression as referred to in this article is when aggression is carried out across national borders against minority groups in other countries who have no relationship with conflicting actors.

The beating case of Chandasilo monk in Malang, East Java, for example, he can be considered as a substitute target which appeared at the wrong place and at the wrong time. The perpetrator, Salim Mubarak, came to the Malang Immigration Office with his wife and three children, to complete the passport for his wife and children (Tempo 2015). However, when he coincidentally met Chandasilo who wore the Kasaya (monk's robe), the hatred against Buddhist radical groups in Myanmar has encouraged him to punch Chandasilo.

There are two main causes of displaced aggression: The availability of target and fear of punishment from initial provocation (Reijntjes et al. 2013). Violent actions against Buddhists in Indonesia can explain this phenomenon. The availability of Indonesian Buddhists who has a closer distance than to ensure the Myanmar government "pays" their actions to the Rohingyas.

Besides psychological reasons, displaced aggression also occurs due to identity similarity. Research conducted by Vasquez, Lickel, and Hennigan analyzed the relationship between shared identity and displaced violence in gang members. Gang members are slowly forming a strong identity among them and attacks from a rival gang or other group are considered as a threat to the valued identity of the gang (Vasquez, Lickel, and Hennigan 2010).

This group-based anger is also analyzed by Stenstrom, Lickel, Denson, and Miller, they concluded that people's in-group identity might wreak their anger towards threatening out-groups (Stenstrom et al. 2008). Groups and individual that have a limited ability to defend themselves, such as women, children, and ethnic and religious minorities, also tend to be the targets of aggression (Woolf and Hulsizer 2003).

\section{Analysis}

\section{a. Actors of Displaced Aggression}

It should be highlighted here that not all Muslims committed violence against Buddhists in Indonesia. The violent actions are taken by small groups who are often committing in many other religious violent actions in Indonesia.

\section{Islamic Defenders Front (Front Pembela Islam / FPI)}

FPI is a controversial Islamic fundamentalist group in Indonesia ${ }^{20}$. Although it declares itself as Islamic defender, many other large moderate Islamic organizations (such as the Nadhatul Ulama and Muhammadiyah) in Indonesia opposed to this group because this group often conducts violence actions in the name of Islam. Bagir et al. (2010) distinguish two faces of FPI: the civil and uncivil mode. The civil mode of this organization presents this group as an ally to the authorities and protector of those in need. However, the uncivil mode of this organization uses demonizing rhetoric (verbal

\footnotetext{
${ }^{20}$ Nisan Kassam, "INDONESIA: The Islamic Defenders Front,” 2017, https://hrwf.eu/indonesiathe-islamic-defenders-front/; Alexander R. Arifianto, "Islamic Defenders Front: An Ideological Evolution?" (RSIS Commentary, 2017), https://www.rsis.edu.sg/wpcontent/uploads/2017/12/CO17228.pdf.
} 
violence or even killing action) of those who deemed deviant ${ }^{21}$.

\section{Islamic State of Syria dan The Levant (ISIL)}

ISIL terrorist group has some followers from Indonesia. According to the USAID Final Report (2016), seven local organization in Indonesia are listed as ISIS members.

The director of Institute for Policy Analysis of Conflict (IPAC), Sidney Jones, sees that the emergence of Rakhine crisis has inspired Indonesian extremists to assist their fellow Muslims or lead to attacks against Myanmar government buildings or officials. The ISIL could also see Arakan Rohingya Salvation Army (ARSA) as a potential partner ${ }^{22}$. A man who beat Chandasilo Buddhist monk on behalf of Muslim Rohingya is also an ISIL member and a police fugitive.

\section{Local Muslim Organizations}

Differ from FPI and ISIL; many other local Muslim organization is not encouraged by an integrated movement with clear doctrine 23 . Another perpetrator of Displaced Aggression against Buddhists in Indonesia is local groups concentrated in certain cities or regions in Indonesia, which have no affiliation with both FPI and ISIL. The Muslim Lawyers Team (Tim Pengacara Muslim) in Aceh, for example, demands a temporary closure of the Buddhist monastery in Aceh due to the Rakhine crisis.

\footnotetext{
${ }^{21}$ Zainal Abidin Bagir et al., "Laporan Tahunan Kehidupan Beragama Di Indonesia 2010" (Yogyakarta, 2010), file://C:/Users/Shary/Downloads/CRCS28022012-87-

196laporan_tahunan_kehidupan_beragama_di_indo nesia_2010 (1) (1).p̄df.

${ }^{22}$ Sidney Jones, "The Shifting Extremist Threat in

Southeast Asia," 2017,

https://iar2015.sites.olt.ubc.ca/files/2017/10/16Sidney-Jones.pdf.

${ }^{23}$ Cherian George, Hate Spin: The Manufacture of Religious Offense and Its Threat to Democracy January 2016 (London: The MIT Press, 2016).
}

\section{Radical Media}

The misuse of social media by radical groups and individuals has been a hot topic for researchers since the emergence of terrorist groups such as $\mathrm{Al}$ Qaeda and ISIS ${ }^{24}$. Hoaxes and hate speech were used by left wing for economic interest, such as the case of Saracen and the Muslim Cyber Army (MCA) (news syndicates accused of spreading thousands of hoaxes and fake news in Indonesia).

The cyber jihadist network known as The Family of Muslim Cyber Army (MCA) is accused of spreading fake news and hate speech. Several allegations were addressed to this network, such as ${ }^{25}$ :

(1) inflame religious and ethnic schisms;

(2) fan paranoia around gay men and lesbians,

(3) alleged communists and Chinese people; and

(4) spread defamatory content to undermine the president

The MCA network also posts hoaxes about Rohingya crisis. They post news about Muslim persecution, but it was mixed up with domestically-inspired vitriol, hatred against Indonesian-Chinese, and even inflamed hatred against respected Indonesian figures ${ }^{26}$. They intensified these hoaxes and hates speeches before the Vesak ceremony, to provoke aggression against Buddhists.

\footnotetext{
${ }^{24}$ Alexander Spencer, "The Social Construction of Terrorism: Media, Metaphors and Policy Implications," Journal of International Relations and Development 15, no. 3 (July 10, 2012): 393 419, https://doi.org/10.1057/jird.2012.4.

${ }^{25}$ The Guardian, "Muslim Cyber Army: A 'fake News' Operation Designed to Derail Indonesia's Leader," 2018, www.theguardian.com/world/2018/mar/13/muslimcyber-army-a-fake-news-operation-designed-tobring-down-indonesias-leader.

${ }^{26}$ Guardian.
} 


\section{b. Understanding the Causes of International Displaced Aggression: Social Identity Analysis on Displaced Aggression}

The social identity theory states that the individual's perception comes from his/her membership on certain social groups ${ }^{27}$. This social identity is based on certain nationalities, races, occupations, sexes, and religions ${ }^{28}$, and an individual can be a member of many different social categories. For example, In Indonesia, a person who is Chinese and also a Buddhist can be classified as Double Minority status. Their double minority status has made them vulnerable to any violent action.

Indonesian Muslim has a strong binding with their religious identity, and even stronger than national identity. For example, Indonesian people have a high curiosity about the life of Muslim minority in other countries. Ayana Jihye Moon who became viral in Indonesia just because she is a South Korean woman who converted to Islam and makes hijab tutorials on Youtube. Her fame came from two reasons: first, Islam in South Korea is a minority religion; thus, when there are Korean people who are Muslim, this becomes a rare thing. Second, Indonesian has long been a fan country of Korean culture. This case proves that the "Self" identity of Indonesian society is more dominated by religious identity than national identity. How the member of "We" can survive in a country with a majority of other religions or "Other," gives its charm for the Indonesian. Therefore, the news about how Muslim Rohingyas within discriminatory actions by the Myanmar government also

\footnotetext{
${ }^{27}$ John C. Turner and Penelope J. Oakes, "The Significance of the Social Identity Concept for Social Psychology with Reference to Individualism, Interactionism and Social Influence," British Journal of Social Psychology 25, no. 3 (September 1986): 237-52, https://doi.org/10.1111/j.20448309.1986.tb00732.x.

${ }^{28}$ Michael A. Hogg et al., "The Social Identity Perspective," Small Group Research 35, no. 3 (June 18, 2004): 246-76, https://doi.org/10.1177/1046496404263424.
}

provides tremendous sympathy from Indonesian Muslim.

Identity and violence have an undeniable linkage. Amartya Sen sees that one reason why violence is closely related to identity exist due to the reductionism meaning of identity ${ }^{29}$. The "singular affiliation" type of reductionism considers that everyone, for practical purposes, is related to only one identity. This identity has a very strong influence in behaving towards other people or groups who have a different identity ${ }^{30}$ The violent actors against Buddhists in Indonesia consider that all Buddhists are single affiliates. Thus the violence committed by Myanmar Buddhists needs should be retaliated to Buddhists in Indonesia.

\section{c. In Group and Out_Group Identity}

This reductionist view of singular affiliation creates a gap in understanding of "Self" and "Other" ${ }^{31}$ and raises a sense of shared destiny with other individuals with the same social group ${ }^{32}$. Social identity is then creating a division between in-group and outgroup, and when a person feels as a part of the group, everything will be viewed from the group's perspective ${ }^{33}$. suggests that the introduction of differences between identity groups (without any conflicting history among those groups) is already sufficient to create

\footnotetext{
${ }^{29}$ Amartya Sen, Identity and Violence (London: W.W Norton, 2006).

${ }^{30}$ Amartya Sen, Reason Before Identity (London: W.W Norton, 1999).

${ }^{31}$ David K. Sherman and Geoffrey L. Cohen, "The Psychology of Self-defense: Self-Affirmation Theory," 2006, 183-242, https://doi.org/10.1016/S0065-2601(06)38004-5. ${ }^{32}$ Bongsoon Cho and Debra L. Connelley, "The Effect of Conflict and Power Differentials on Social Identity and Intergroup Discrimination," SSRN Electronic Journal, 2002, https://doi.org/10.2139/ssrn.320286. 33 Jan E. Stets and Peter J. Burke, "Identity Theory and Social Identity Theory," Social Psychology Quarterly 63, no. 3 (September 2000): 224, https://doi.org/10.2307/2695870.
} 
discrimination of in-group and out-group groups ${ }^{34}$.

Therefore, the threat came from out-group can be directly assumed as a threat to the member of in-group, so the conflict dynamics between groups becomes difficult to avoid ${ }^{35}$. This threat can affect problem-solving action. The greater the perceived threat, the more problem-solving ability decreases, compared with the group who receives the least threat. These threats can be direct and indirect. The target of direct threat is individuals/groups that have a certain social identity, while indirect threats are targetted to the symbols of identity 36.

The globalization of information and communication then widened the gap between these social groups into a wider arena, beyond state boundaries. Huntington raises the term a clash of civilizations: a cultural entity capable of replacing the traditional state entities, where the history of these civilizations collide with one another ${ }^{37}$. In the case of the Rakhine crisis, Indonesian people do not see this as a matter of Myanmar's national security issue or their dissent from a historical perspective. They see this conflict as an identity conflict between Muslim Rohingya and the predominantly Buddhist Myanmar government. Indonesia and other countries such as Turkey also see this as evidence of a grand conspiracy against Islam. The 2018 survey from Universitas Islam Hidayatullah and Convey Indonesia, shows that $62.11 \%$ of teachers and $55.08 \%$ of students in Indonesia agree that Muslims are under zalim / unjust

\footnotetext{
${ }^{34}$ Henri Tajfel, "Experiments in Intergroup Discrimination," Scientific American 223, no. 5 (November 1970): 96-102, https://doi.org/10.1038/scientificamerican1170-96. ${ }^{35}$ Martin W. Rempel and Ronald J. Fisher, "PERCEIVED THREAT, COHESION, AND GROUP PROBLEM SOLVING IN INTERGROUP CONFLICT," International Journal of Conflict Management 8, no. 3 (March 1997): 216-34, https://doi.org/10.1108/eb022796.

${ }^{36}$ Rempel and Fisher.

${ }^{37}$ Samuel Huntington, The Clash of Civilization and the Remaking of World Order (New York: Simon \& Schuster, 1996).
}

situation ${ }^{38}$. Although Islam is the major religion in Indonesia, and certainly not treated unfairly, the zalim feeling fell from the condition of their kinship member of "brother" and "sister." All believers in the Qur'an have been declared brother and sister :

"Interpreters of the Holy Quran (Mufassireen) are convinced that in citing the verse "blessing" means unity among Muslims. And brotherhood among Muslims can only be established on the ground of Towheed. Unity is presented as the primary member and the track axis in the Sunnah and Islamic traditions" ${ }^{39}$.

The brotherhood among Muslims sees that because the Muslim Rohingyas are treated with violence, it is then becomes the duty of fellow Indonesian Muslims to stop or respond to it.

The term Ummah is another example of how the solidarity among Muslim grow, felt and accepted among its member. Ummah stands for the solidarity of the Muslim community, beyond state borders ${ }^{40}$. Their same religious identity was seen as and the Rakhine crisis is seen as a threat to Ummah. The recognition of Brother and sister is not defined by blood relations or national identity. Instead, it was defined by religious similarity. This is why the violent actions against nonMuslim (even with the same national identity) accepted and understandable under some circumstances.

Even the Indonesian government provide humanitarian assistance based on religious similarity. President Joko Widodo highlighted

\footnotetext{
${ }^{38}$ PPIM, "Api Dalam Sekam: Keberagaman Muslim Gen-Z. Convey Indonesia,” 2018, https://conveyindonesia.com/assets/pdf/infographic Gen Z (1).pdf.

${ }^{39}$ Maqbool Hassan, "Unity of Muslim Ummah, It's Need, Importance and Suggestions," International Multilingual Journal of Contemporary Research 3 , no. 1 (2015): 26-32.

${ }^{40}$ (Roy 2004, p.1)
} 
the importance of diplomacy in solving humanitarian crises ${ }^{41}$ :

"We have dispatched ten containers to help our brothers, especially the Muslim community, in Rakhine State. They contain instant noodles, baby food, wheat, cereals, and sarungs. These items were requested."

As a member of the Association of Southeast Asian Nations/ASEAN, the Indonesian government must comply with the non-intervention principle. Indonesia is certainly not allowed to intervene in Myanmar's internal conflicts. However, the insistence on the social identity of Indonesia as the country with the largest Muslim population in the world forced the country to slightly disregard the principle of non-intervention and start providing humanitarian assistance. In September 2017, Indonesia sent 34 tons of humanitarian aid to Rohingya refugees in the nearby district of Myanmar-Bangladesh border 42.

\section{d. Displaced Aggression and Intergroup Bias}

To maintain group membership, individuals tend to prioritize their own group (in-group) compared to other groups (outgroup). This prioritization creates an intergroup bias when the individual exhibits a non-objective assessment of his/her own group ${ }^{43}$. One form of Intergroup bias is the ultimate attribution error phenomenon, in which

\footnotetext{
${ }^{41}$ Eko Prasetyo, "Jokowi Hopes for Peace in Rakhine State, Sends Humanitarian Aid to Myanmar," 2016, http://jakartaglobe.id/news/jokowi-hopes-peacerakhine-state-sends-humanitarian-aid-myanmar. ${ }^{42}$ The Wasington Times, "The Latest: Indonesia Sends 34 Tons of Aid for Rohingya," September 12, 2017,

https://www.washingtontimes.com/news/2017/sep/ 12/the-latest-indonesia-sends-34-tons-of-aid-forrohi/.

${ }^{43}$ Turner and Oakes, "The Significance of the Social Identity Concept for Social Psychology with Reference to Individualism, Interactionism and Social Influence."
}

individuals tend to provide better explanations for members, than to other groups ${ }^{44}$.

Example of intergroup bias is the ultimate attribution error phenomenon and the black sheep effect. The ultimate attribution error occurs when individuals tend to provide better explanations for members, than to other groups while the black sheep effect occurs when group member always gets a better judgment compared to other groups ${ }^{45}$.

Concerning the situation in Indonesia, many Islamic groups have intergroup biased when they view the Rohingya crisis as an attempt of Myanmar Buddhist government to combat Muslim Rohingyas, and they also unaware of other factors such as history and politics in Myanmar. In fact, their violent actions against Indonesian Buddhists that have nothing to do with the conflict in Myanmar is not considered wrong, as they compare it with the treatment of the Myanmar government against the Rohingyas.

\section{e. The Imagined Communities and Unity Against Common Enemy}

According to Hans Kohn, nationalism is a notion that the highest allegiance of individuals must be left to the nation-state. There are two forms of nationalism: nationalism as a voluntary action of its member, and nationalism as an irrational concept ${ }^{46}$. In line with Kohn's latest type of nationalism, nationalism according to Benedict Anderson is a community that can only be imagined, because even the smallest nation, does not know all its members. In other words, nationalism arises from the delusion of its members ${ }^{47}$.

\footnotetext{
${ }^{44}$ Miles Hewstone, Mark Rubin, and Hazel Willis, "Intergroup Bias," Annual Review of Psychology 53, no. 1 (February 2002): 575-604, https://doi.org/10.1146/annurev.psych.53.100901.1 35109.

${ }^{45}$ Hewstone, Rubin, and Willis.

${ }^{46}$ Hans Kohn, Nationalism: Its Meaning and History (Macmillan, 1965).

${ }^{47}$ Benedict Anderson, Imagined Communities: Reflections on the Origin and Spread of Nationalism (London: Verso, 1991).
} 
The non-appearance of the common enemy also bring this nation divided and fight among its members. The common enemy is highly important for Indonesia to bring common feelings among Indonesian. This is understandable since the independence of Indonesia resulted from the struggle against Dutch colonial. This is how Indonesia is holding its nations during the independence era. After the common enemy (Dutch and Japanese colonials) is defeated in 1945, this nation fell into another battle against each other. The rebellion against government rose under Islamic identity. The Darul Islam rebellion movement to bring the Khilafah in Indonesia, for example, almost made this nation fractioned in the 1940 s to 1960 s.

Anderson sees the emergence of nationalism from the historical experience of various nations, including Indonesia. The postcolonial nationalism in Asia and Africa resulting from the emulation of the nationalism history in Europe. The nationalism of postcolonial society was formed based on a difference as a form of resistance to colonialism $^{48}$.

The concept of imagined community can be used to analyze both national and religious social identity in Myanmar conflict cases. First, Indonesian nationality has been defeated by religious identity. Indonesian nationalism is a form of deliberate nationalism where the awareness of the nation's identity resulted from the history of suffering and discrimination by the Dutch colonial. The early Indonesian nationalism came from the contradiction between 'Self' versus colonialism of 'Other'. However, after independence, the Indonesian nation seemed to have lost the sense of unity against foreign enemy, and instead turned fellow citizens into "common enemies". This is evidenced by the displaced violence committed by Indonesian Buddhists. Their religious identity is more powerful than nationalist identity as an Indonesian, so that religious violence among fellow Indonesian

48 Anderson. takes place. This case can also be viewed as a discourse of Anderson's secular nationalism that in fact at odds with the veil of religious nationalism used by FPI, ISIL, and MCA, which is simply a justification for the acts of violence they have committed.

Second, this conflict re-affirms the concept of imagined community promoted by Benedict Anderson, that nationalism emerged from the cultural system, one of which is the religious community. Indonesian Muslim has never interacted directly with Rohingya Muslim in Myanmar. Yet religious similarity raises an imaginary closeness among a group of Muslims in Indonesia with Rohingyas in Myanmar. The consequence of this imaginary closeness is the emergence of displaced aggression against Indonesian Buddhists.

\section{Conclusion}

This research seeks to analyze the phenomenon of violence against Buddhists in Indonesia. Some of this violence cases are: The threat of forced closure of Vihara in Medan and bomb explosion on Ekayana Vihara in West Jakarta in 2013; The beating of Buddhist monk Malang by an ISIS member, and hate speech days before Vesak celebration in 2015; and later, the demonstration at the Borobudur Temple area in 2017. Uniquely, these violent actions were done to avenge the Myanmar Buddhist government. Two different countries, with victims who are not the main perpetrator. The only cause of these violent actions is religion similarity.

However, why should this violence be done against fellow Indonesian citizens? The term displaced aggression is used to answer this question. Displaced aggression is a violent behavior against non-perpetrator, where the displaced target is weaker, and sometimes violence happens to them because they are in the wrong place and at the wrong time. Buddha is a minority religion in Indonesia, and its adherents become a soft target for violent actions.

Then, why does this displaced aggression happen? By using the theory of social identity, 
it can be concluded that the reductionist view of singular affiliation creates a gap in understanding of 'Self' and 'Other'. The brotherhood among Muslims sees that because the Muslim Rohingyas are treated with violence, and it is the duty of fellow Indonesian Muslims to stop or respond against it. It then creates an intergroup bias when individuals tend to prioritize their own group (in-group) compared to other groups (outgroup) when perpetrators of displaced aggressions view the Rohingya crisis as an attempt of Myanmar Buddhist government to combat Muslim Rohingyas. And at last, this phenomena reaffirms the concept of imagined community by Benedict Anderson.

\section{References}

Allen, Johnie J., and Craig A. Anderson. "Aggression and Violence: Definitions and Distinctions." The Wiley Handbook of Violence and Aggression, September 8, 2017, 1-14. https://doi.org/10.1002/9781119057574. whbva001.

Anderson, Benedict. Imagined Communities: Reflections on the Origin and Spread of Nationalism. London: Verso, 1991.

Anderson, Craig A., and Brad J. Bushman. "Human Aggression." Annual Review of Psychology 53, no. 1 (February 2002): 27-51.

https://doi.org/10.1146/annurev.psych.53 .100901 .135231 .

Arifianto, Alexander R. "Islamic Defenders Front: An Ideological Evolution?" RSIS Commentary, 2017.

https://www.rsis.edu.sg/wpcontent/uploads/2017/12/CO17228.pdf.

Aron, Gabrielle. "Reframing the Crisis in Myanmar's Rakhine State," 2018. usip.org/publications/2018/01/reframingcrisis-myanmars-rakhine-state.

Badan Pusat Statistik Indonesia. "Statistik Politik 2017." Jakarta, 2017.

Bagir, Zainal Abidin, Suhadi Cholil, Endy Saputro, Budi Asyhari, and Mustaghfiroh Rahayu. "Laporan Tahunan Kehidupan Beragama Di Indonesia 2010." Yogyakarta, 2010. file://C:/Users/Shary/Downloads/CRCS28022012-87- 196laporan_tahunan_kehidupan_beraga ma di indonesia 2010 (1) (1).pdf.

Berkowitz, Leonard. "Frustration-Aggression Hypothesis: Examination and Reformulation." Psychological Bulletin 106, no. 1 (1989): 59-73. https://doi.org/10.1037/00332909.106.1.59.

Bhagavant. "Demo Myanmar Yang Salah Alamat Di Vihara Borobudur Medan." 2013.

https://berita.bhagavant.com/2013/05/06/ demo-myanmar-yang-salah-alamat-divihara-borobudur-medan.html. . "Isu Rohingya, Buddhis Indonesia Kembali Dapat Ancaman Teror." 2015. https://berita.bhagavant.com/2015/05/31/ isu-rohingya-buddhis-indonesia-kembalidapat-ancaman-teror.html.

Cho, Bongsoon, and Debra L. Connelley. "The Effect of Conflict and Power Differentials on Social Identity and Intergroup Discrimination." SSRN Electronic Journal, 2002. https://doi.org/10.2139/ssrn.320286.

Derrida, Jacques. Positions. Chicago: University of Chicago Press, 1981.

Fahmi, Yusron. "Sikap Majelis-Majelis Agama Buddha Soal Kekerasan Atas Rohingya," September 3, 2017. https://www.liputan6.com/news/read/308 0555/sikap-majelis-majelis-agamabuddha-soal-kekerasan-atas-rohingya.

George, Cherian. Hate Spin: The Manufacture of Religious Offense and Its Threat to Democracy January 2016. London: The MIT Press, 2016.

Glossop, Ronald J. "Confronting War: An Examination of Humanity's Most Pressing Problem." Peace \& Change 10, no. 3-4 (October 1984): 181-82. https://doi.org/10.1111/j.14680130.1984.tb00534.x.

Guardian, The. "Muslim Cyber Army: A 'fake News' Operation Designed to Derail Indonesia's Leader," 2018. www.theguardian.com/world/2018/mar/1 3/muslim-cyber-army-a-fake-newsoperation-designed-to-bring-downindonesias-leader.

Hartati, Anna Yulia. "Studi Eksistensi Etnis Rohingya Di Tengah Tekanan Pemerintah Myanmar." JURNAL HUBUNGAN INTERNASIONAL 2, no. 1 (2013): 7-17. 
file://C:/Users/Shary/Downloads/297-

906-1-PB.pdf.

Hassan, Maqbool. "Unity of Muslim Ummah, It's Need, Importance and Suggestions." International Multilingual Journal of Contemporary Research 3, no. 1 (2015): 26-32.

Hewstone, Miles, Mark Rubin, and Hazel Willis. "Intergroup Bias." Annual Review of Psychology 53, no. 1 (February 2002): 575-604.

https://doi.org/10.1146/annurev.psych.53 .100901.135109.

Hogg, Michael A., Dominic Abrams, Sabine Otten, and Steve Hinkle. "The Social Identity Perspective." Small Group Research 35, no. 3 (June 18, 2004): 24676.

https://doi.org/10.1177/10464964042634 24.

Huntington, Samuel. The Clash of Civilization and the Remaking of World Order. New York: Simon \& Schuster, 1996.

Jones, Sidney. "The Shifting Extremist Threat in Southeast Asia," 2017.

https://iar2015.sites.olt.ubc.ca/files/2017/ 10/16-Sidney-Jones.pdf.

Kassam, Nisan. "INDONESIA: The Islamic Defenders Front," 2017. https://hrwf.eu/indonesia-the-islamicdefenders-front/.

Kohn, Hans. Nationalism: Its Meaning and History. Macmillan, 1965.

Nadya, Natahadibrata. "Bomb Threatens Pluralism." The Jakarta Post. 2013. https://www.thejakartapost.com/news/20 13/08/06/bomb-threatens-pluralism.html.

Nasution, Aulia Rosa. "The Crime of Genocide on the Rohingya Ethnic in Myanmar from the Perspective of International Law and Human Rights." PADJADJARAN Jurnal Ilmu Hukum (Journal of Law) 5, no. 1 (May 13, 2018): 182-206. https://doi.org/10.22304/pjih.v5n1.a10.

Pedersen, William C., Candace Gonzales, and Norman Miller. "The Moderating Effect of Trivial Triggering Provocation on Displaced Aggression." Journal of Personality and Social Psychology 78, no. 5 (2000): 913-27.

https://doi.org/10.1037/00223514.78.5.913.

PPIM. "Api Dalam Sekam: Keberagaman Muslim Gen-Z. Convey Indonesia,"
2018.

https://conveyindonesia.com/assets/pdf/i nfographic Gen Z (1).pdf.

Prasetyo, Eko. "Jokowi Hopes for Peace in Rakhine State, Sends Humanitarian Aid to Myanmar," 2016.

http://jakartaglobe.id/news/jokowihopes-peace-rakhine-state-sendshumanitarian-aid-myanmar.

Rempel, Martin W., and Ronald J. Fisher. "PERCEIVED THREAT, COHESION, AND GROUP PROBLEM SOLVING IN INTERGROUP CONFLICT." International Journal of Conflict Management 8, no. 3 (March 1997): 216-34. https://doi.org/10.1108/eb022796.

Roy, Olivier. Globalised Islam: The Search for a New Ummah. London: Hurst \& Company, 2004.

Sen, Amartya. Identity and Violence. London: W.W Norton, 2006.

- Reason Before Identity. London: W.W Norton, 1999.

Sherman, David K., and Geoffrey L. Cohen. "The Psychology of Self-defense: Self-Affirmation Theory," 183-242, 2006. https://doi.org/10.1016/S00652601(06)38004-5.

Spencer, Alexander. "The Social Construction of Terrorism: Media, Metaphors and Policy Implications." Journal of International Relations and Development 15, no. 3 (July 10, 2012): 393-419. https://doi.org/10.1057/jird.2012.4.

"Spreading Hatred against Buddhists 'Worsens Rohingya Conflict."” The Jakarta Post, November 26, 2016.

https://www.thejakartapost.com/news/20 16/11/26/spreading-hatred-againstbuddhists-worsens-rohingyaconflict.html.

Stepan, Alfred C. "Religion, Democracy, and the "Twin Tolerations." Journal of Democracy 11, no. 4 (2000): 37-57. https://doi.org/10.1353/jod.2000.0088.

Stets, Jan E., and Peter J. Burke. "Identity Theory and Social Identity Theory." Social Psychology Quarterly 63, no. 3 (September 2000): 224. https://doi.org/10.2307/2695870.

Suherdjoko. "Peaceful Rohingya Solidarity Rally Held near Borobudur Temple." The Jakarta Post. September 9, 2017. http://www.thejakartapost.com/news/201 
7/09/09/peaceful-rohingya-solidarityrally-held-near-borobudur-temple.html.

Tajfel, Henri. "Experiments in Intergroup Discrimination." Scientific American 223, no. 5 (November 1970): 96-102. https://doi.org/10.1038/scientificamerica n1170-96.

Tajuddin, Azlan. "Statelessness and Persecution of the Rohingyas in Myanmar: Time for Serious International Intervention." Social Science Spectrum 3, no. 3 (2017): 128-40.

http://www.socialspectrum.in/index.php/ sp/article/view/107/98.

Tempo. "Biksu Ini Beri Maaf Anggota ISIS Yang Pukul Dirinya.” April 2, 2015. https://nasional.tempo.co/read/654874/bi ksu-ini-beri-maaf-anggota-isis-yangpukul-dirinya.

Times, The Wasington. "The Latest: Indonesia Sends 34 Tons of Aid for Rohingya," September 12, 2017. https:/www.washingtontimes.com/news/ 2017/sep/12/the-latest-indonesia-sends- 34-tons-of-aid-for-rohi/.

Tobing, D H. "The Limits and Possibilities of the ASEAN Way: The Case of Rohingya as Humanitarian Issue in Southeast Asia." KnE Social Sciences 3, no. 5 (May 23, 2018): 148. https://doi.org/10.18502/kss.v3i5.2331.

Turner, John C., and Penelope J. Oakes. "The Significance of the Social Identity Concept for Social Psychology with Reference to Individualism, Interactionism and Social Influence." British Journal of Social Psychology 25, no. 3 (September 1986): 237-52. https://doi.org/10.1111/j.20448309.1986.tb00732.x.

Ullah, Akm Ahsan. "Rohingya Refugees to Bangladesh: Historical Exclusions and Contemporary Marginalization." Journal of Immigrant \& Refugee Studies 9, no. 2 (April 2011): 139-61. https://doi.org/10.1080/15562948.2011.5 67149 . 